Наносистели, нанолатеріали, нанотехнології Nanosistemi, Nanomateriali, Nanotehnologii 2019, т. 17, № 4, сc. 661-678 (c) 2019 ІМФ (Інститут металофізики ім. Г. В. Курдюмова НАН України) Надруковано в Україні. Фотокопіювання дозволено тільки відповідно до ліцензії

PACSnumbers: 62.20.Qp, 62.23.Kn, 81.15.Jj, 81.40.Pq, 81.65.Lp, 81.70.Jb, 82.80.-d

\title{
Structure and Properties of Piston Rings with Ion-Plasma Multilayer Nanohardening
}

T. S. Skoblo ${ }^{1}$, O. I. Sidashenko ${ }^{1}$, I. E. Garkusha ${ }^{2}$, V. S. Taran ${ }^{2}$, R. M. Muratov ${ }^{2}$, E. A. Satanovskiy ${ }^{3}$, O. K. Oleynik ${ }^{3}$, T. V. Maltsev ${ }^{1}$, V. M. Romanchenko ${ }^{1}$, and O. D. Martynenko ${ }^{1}$

${ }^{1}$ Kharkiv Petro Vasylenko National Technical University of Agriculture, 44, Alchevskikh Str.,

UA-61002 Kharkiv, Ukraine

${ }^{2}$ National Science Centre 'Kharkiv Institute of Physics and Technology', 1, Akademichna Str.,

UA-61108 Kharkiv, Ukraine

${ }^{3}$ State Enterprise 'Malyshev Plant',

126, Plekhanivs'ka Str.,

UA-61037 Kharkiv, Ukraine

A method and application parameters for hardening of oil-scraper piston rings by multilayer ion-plasma $\mathrm{TiN} / \mathrm{CrN}$ nanocoating are proposed. An increase in the microhardness of piston rings by 143 times relative to serial rings is shown. An increase in the wear resistance of piston rings by 12 and 15.7 times is achieved at sliding speeds of 1 and $1.3 \mathrm{~m} / \mathrm{s}$, respectively. The chemical-composition study of friction surface of the rings with hardening is carried out. Structurization of the adjacent surface of both variants of rings due to cyclic effects during friction is revealed. A method for estimating diffusion of the Fe rings towards the strengthening multilayer coating is proposed.

Запропоновано метод і параметри зміцнення мастилознімних поршневих кілець багатошаровим йонно-плазмовим нанопокриттям $\mathrm{TiN} / \mathrm{CrN}$. Показано збільшення мікротвердости поршневих кілець у 143 рази в порівнянні з серійними кільцями. Досягнуто збільшення зносостійкости поршневих кілець у 12 і 15,7 рази при швидкостях ковзання в 1 і 1,3 м/с відповідно. Проведено дослідження хемічного складу поверхні тертя кілець із зміцненням. Виявлено структуризацію прилеглої поверхні обох варіянтів кілець при циклічному впливі процесу тертя. Запропоновано метод оцінки дифузії Fe кілець у бік зміцнювального багатошарового покриття. 
Предложены метод и параметры упрочнения маслосъёмных поршневых колец многослойным ионно-плазменным нанопокрытием $\mathrm{TiN} / \mathrm{CrN}$. Показано увеличение микротвёрдости поршневых колец в 143 раза по сравнению с серийными кольцами. Достигнуто увеличение износостойкости поршневых колец в 12 и 15,7 раза при скоростях скольжения в 1 и $1,3 \mathrm{~m} / \mathrm{c}$ соответственно. Проведено исследование химического состава поверхности трения колец с упрочнением. Обнаружена структуризация прилегающей поверхности обоих вариантов колец при циклическом воздействии процесса трения. Предложен метод оценки диффузии $\mathrm{Fe}$ колец в сторону упрочняющего многослойного покрытия.

Key words: piston rings, ion-plasma multilayer nanocoating, wear, microhardness, X-ray microanalysis, diffusion.

Ключові слова: поршневі кільця, йонно-плазмове багатошарове нанопокриття, знос, мікротвердість, мікрорентгеноспектральна аналіза, дифузія.

Ключевые слова: поршневые кольца, ионно-плазменное многослойное нанопокрытие, износ, микротвёрдость, микрорентгеноспектральный анализ, диффузия.

(Received 3 May, 2019)

\section{INTRODUCTION}

In operating conditions that differ in the type of engines, the parameters of the actual loads, both different sizes of piston rings and the material for their manufacture are used. The main parameters varying under their operating conditions are the speed of sliding and pressure on their working surface. These processes determine their physicochemical and structural changes that characterize wear. A detailed analysis of changes in operating parameters under specific conditions can only be carried out based on the information obtained about their influence and the choice of the most effective method of hardening and the use of parts.

This study presents the results that analyse the effect of different sliding speeds from 0.7 up to $1.6 \mathrm{~m} / \mathrm{s}$ on the wear of hardened piston rings with an ion-plasma coating. Of particular interest are sliding speeds of 1.0 and $1.3 \mathrm{~m} / \mathrm{s}$, which are accompanied by both the same ratio of components during the test and a sharp drop in the proportion of the coating with a different friction path.

The results of previous studies conducted by the authors to determine the degree and nature of wear of serial oil-scraper piston rings of the diesel generator (engine) D100 confirmed their low wear resistance [1].

To solve the problem of increasing their operational durability, 
the working surfaces of such grey cast iron rings were hardened using $\mathrm{TiN} / \mathrm{CrN}$ multilayer ion-plasma nanocoating and individual wear resistance was evaluated under different friction conditions $[2,3]$. So, in each case, a multiple decrease in wear of the hardened rings relatively to serial ones was revealed. However, when taking into account different operating modes of the engine (acceleration and braking) and, consequently, different moving speeds of the piston group, a consistent comparative assessment of the physical and mechanical properties at different sliding speeds of such rings is of great interest, since it does not appear to predict their changes in operation possible.

Purpose of the work is determination of the wear rate at different sliding speeds of the oil-scraper piston rings of the diesel engine D100, hardened by multilayer ion-plasma nanocoating $\mathrm{TiN} / \mathrm{CrN}$ and evaluation of diffusion processes developing during the life cycle of their operation.

\section{OBJECT, MATERIALS AND RESEARCH METHODS}

An object of the research is the process of wear of the oil-scraper piston rings of the engine D100 before and after their hardening. The cross section of the ring with a working surface of $0.2 \mathrm{~mm}$ high, that Figs. 1 shows, was analysed. The working surface is designed to remove the oil from the walls of the cylinder into the engine crankcase, which prevents it from entering the combustion chamber.

To assess the degree of the wear resistance increase of the rings, a multilayer ion-plasma coating of the $\mathrm{TiN} / \mathrm{CrN}$ system was applied on Bulat-type equipment. The deposition of the coating was carried out at an arc current $I=100 \mathrm{~A}$ with a substrate bias voltage of $U=-200 \mathrm{~V}$. Alternately, 6 layers of $\mathrm{CrN}$ and 5-TiN were applied,

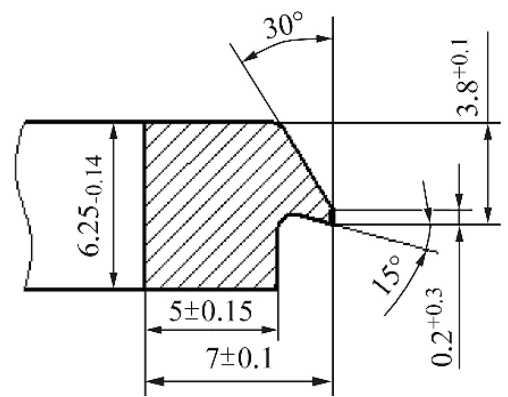

Figs. 1. A sketch of the cross section of the oil-scraper piston ring of D100 diesel engine. 
pre-spraying a sublayer of pure $\mathrm{Cr}$ of $50 \mathrm{~nm}$ thickness. The thickness of the $1^{\text {st }}$ layer of TiN is $49 \mathrm{~nm}$, and the $\mathrm{CrN}$ is $240 \mathrm{~nm}$. The $\mathrm{CrN} / \mathrm{TiN}$ ratio was 5.8. The total thickness of the multilayer coating reached $1.7 \mu \mathrm{m}$ (taking into account the chromium sublayer).

According to serial manufacturing technology, these products are subjected to galvanic tinning to reduce the period of their burn-in due to the formation of a tin layer on the working surface of the ring. The tin coating has a non-uniform grain structure consisting of individual fragments and ironed areas. Serial rings were tested along with the TiN/CrN ion-plasma coating hardened ones for comparative evaluation of their tendency to wear.

To determine the nature and rate of wear of such rings, bench tests were performed on a specialized machine under conditions of sliding friction during reciprocating motion. In the machine was installed one sample taken from the cylinder liner and two ones from the piston rings of the compared variants. The moving part was a sample cylinder liner. Samples of cylinder liners are made of

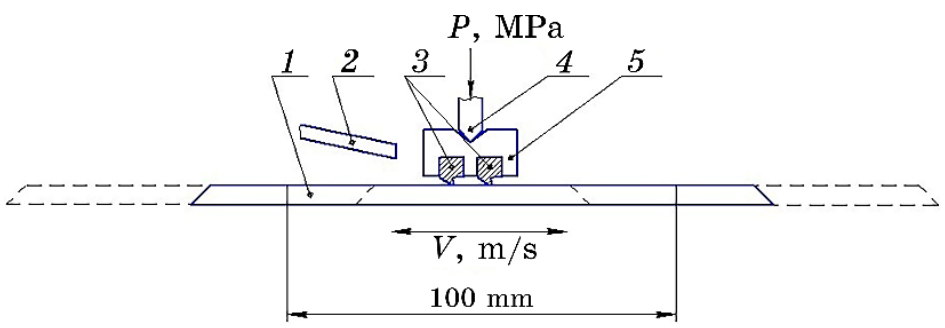

Figs. 2. A scheme of bench tests samples of oil-scraper piston rings. 1sample cylinder liner; 2-drip feed oil pipe; 3-samples of oil-scraper piston rings; 4-cargo; 5-sample holder.

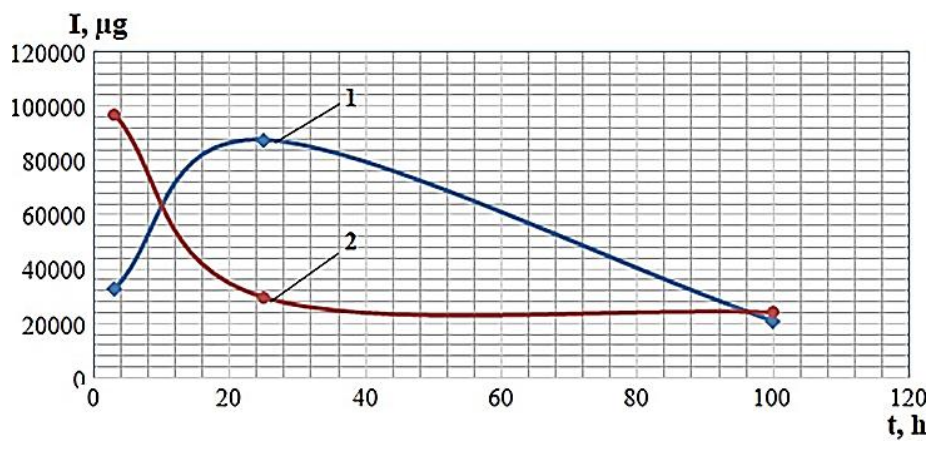

Figs. 3. Wear samples of the cylinder liners at a speed of $1.3 \mathrm{~m} / \mathrm{s}: 1$-wear of the cylinder liners that worked with the hardened rings; 2 -wear of the cylinder liners that worked with the serial ones. 
grey cast iron and subjected to phosphatization (serial technology).

The constant moving speed of the moving samples for each variant was 1 and $1.3 \mathrm{~m} / \mathrm{s}$. The value of the specific pressure on the working surface of the ring was $0.8 \mathrm{MPa}$. This allowed obtaining a modelling process of wear for a shorter test period. The scheme of bench tests samples is presented in Figs. 2.

The length of the stroke of the cylinder liner sample was $100 \mathrm{~mm}$ (Figs. 2). The feed of SAE 40 oil in the friction zone was 1-2 drops per minute. The total test time was 100 hours, of which the first stage was 3 hours, the second stage of the main tests was 25 hours, and the third stage of the main tests was 72 hours. The total length of the traversed friction path for specimens tested at a speed of 1 $\mathrm{m} / \mathrm{s}$ was of $360 \mathrm{~km}$, and at $1.3 \mathrm{~m}$, it was of $468 \mathrm{~km}$. Between the stages of testing, the level of weight wear, the change in microhardness, and the height of the working surface of the rings were recorded. After testing, the working surface of the rings samples was evaluated by X-ray microanalysis to determine changes in the chemical elements of the ion-plasma coating.

\section{RESEARCH RESULTS}

For all stages of testing, the total weight wear of cylinder liners (I) installed in a pair with the hardened rings is $6 \%$ lower at a speed of $1.3 \mathrm{~m} / \mathrm{s}$ (Figs. 3), compared with the serial ones. At the same speed, during the first stage of the test, the wear of the cylinder liner, which worked in a pair with the hardened rings, is 3 times higher than the serial ones. This is explained by the presence of tin coating on serial products, intended for accelerated run-in of tribopairs. At the second stage of testing, a higher wear (3 times) is observed for the cylinder liner, which worked in tandem with the serial rings, relatively the hardened ones by the coating. At the third stage of testing, the weight wear of the cylinder liner, which worked with the hardened rings, is by $13 \%$ lower than the serial ones. It should be noted that the total wear rate of the cylinder liners, assessed by weight loss, paired with the hardened piston rings is also by $6 \%$ lower. Considering the high microhardness of rings with the ionplasma coating, the processes of local transfer of material from the cylinder liner surface were recorded, which caused increased wear at the initial stage of testing (Figs. 3).

Another picture is observed at a sliding speed of $1 \mathrm{~m} / \mathrm{s}$. The total weight wear of the cylinder liners (I) tested with the hardened rings is by $42 \%$ higher than serial ones (Figs. 4). It follows that increased wear is characteristic of the cylinder liner that worked in a pair with the hardened rings, which also falls on the period of runin. In this case, the weight wear is 3 times higher, compared with 


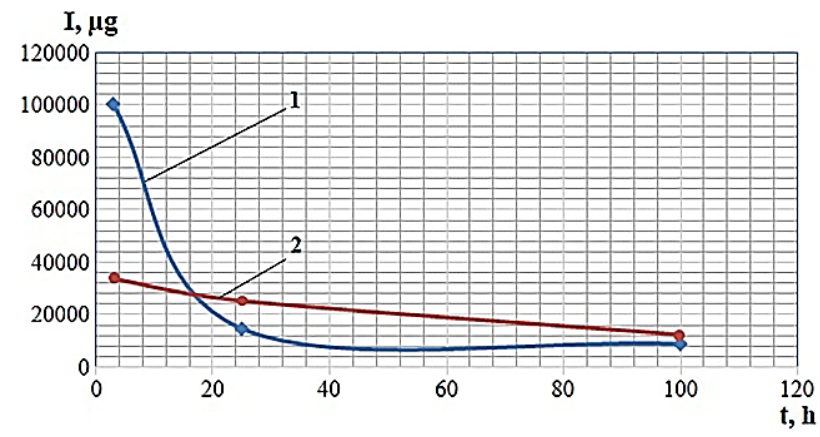

Figs. 4. Wear samples of the cylinder liners at a speed of $1 \mathrm{~m} / \mathrm{s}$ : 1 -wear of the cylinder liners that worked with the hardened rings; 2 -wear of the cylinder liners that worked with the serial ones.

the cylinder liner, tested with the serial rings. This is explained by the presence of tin coating on the serial products, intended for accelerated run-in of tribopairs. However, at the second stage of testing, at the same speed, the weight wear of the cylinder liner, which worked in a pair with hardened rings, decreases by $43 \%$ compared to the serial ones, and at the third stage, it decreases by $29 \%$. At the same time, the wear rate of cylinder liners, estimated by weight loss, worked in a pair with hardened piston rings is by $42 \%$ lower.

A slight gain of the hardened rings of $1000 \mu \mathrm{g}$ at the $2^{\text {nd }}$ and $3^{\text {rd }}$ stages (Figs. 5) is also associated with the local adhesion of individual zones of the friction surfaces. Evaluation results are characteristic of higher wear rates of the serial rings. Such process of hardening by the ion-plasma coating at a higher speed of testing showed that wear decreases by 12 times.

The increase of the samples weight of both variants of the rings at the last stage of testing (Figs. 6) at a sliding speed of $1 \mathrm{~m} / \mathrm{s}$ is also associated with the local adhesion of individual zones of the friction surfaces. The test results indicate about a high rate of the serial rings wear, and with an ion-plasma coating ones, they show that it decreases by 15.7 times.

Table 1 shows the increase of the working surfaces height of the serial and hardened rings after testing at a sliding speed of 1.3 $\mathrm{m} / \mathrm{s}$, and Table 2 shows the same indicator of the rings at a sliding speed of $1 \mathrm{~m} / \mathrm{s}$ respectively. The height of the working surfaces of the serial rings after testing increased on average by $0.04 \mathrm{~mm}$, and the height of the hardened rings increased by $0.01 \mathrm{~mm}$. The observed is the result of the process development of plastic deformation of the rings working surfaces, especially in the absence of hardening. The wear rate by changing the height of the ring working surfaces shows that, for hardened ones, it is lower by $\cong 4$ times 


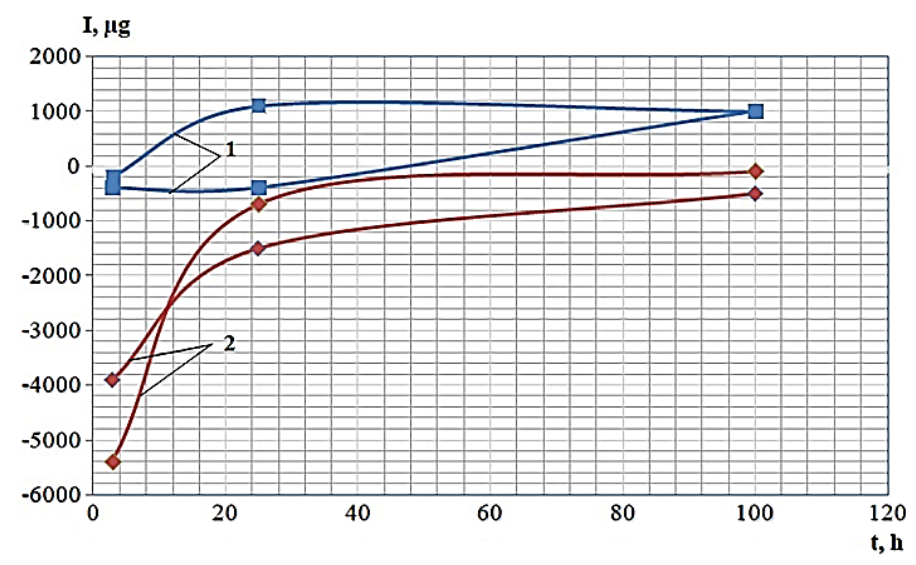

Figs. 5. Degree of the oil-scraper piston rings wear at a sliding speed of $1.3 \mathrm{~m} / \mathrm{s}$ : 1 - wear of the hardened rings; 2 -wear of the serial ones.

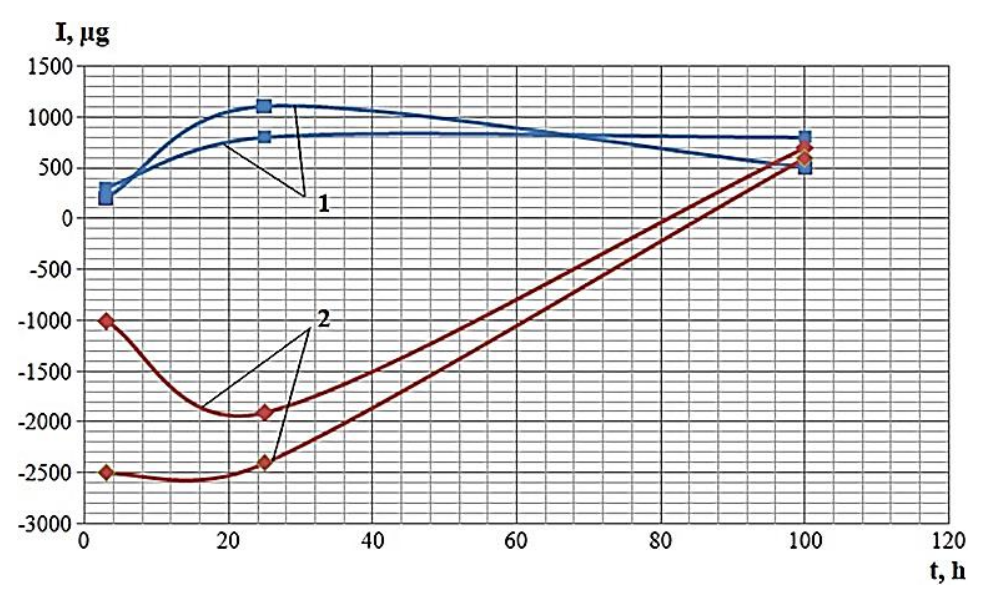

Figs. 6. Degree of the oil-scraper piston rings wear at a sliding speed of 1 $\mathrm{m} / \mathrm{s}: 1-$ wear of the hardened rings; 2 -wear of the serial ones.

at both friction speeds.

The tin coating ensures the stability of indicators only during the period of running-in, and after the $2^{\text {nd }}$ stage of testing, the difference in the degree of hardening is recorded (Figs. 7, $a, b$ ). This trend is characteristic of both sliding speeds. The average initial microhardness of the rings samples with TiN/CrN coating is 148 times higher than the serial ones before testing. The microhardness of the hardened rings after the $2^{\text {nd }}$ stage of testing increases by 3 times, after the $3^{\text {rd }}$-by 2 times relatively to the serial ones at a speed of $1.3 \mathrm{~m} / \mathrm{s}$. The microhardness of the hardened rings after 
TABLE 1. Increasing the height of the working surfaces of the rings at a sliding speed of $1.3 \mathrm{~m} / \mathrm{s}$.

\begin{tabular}{|c|c|c|}
\hline \multicolumn{2}{|c|}{ Variant of piston rings } & $\begin{array}{l}\text { Height } \\
\text { of the rings working surfaces, mm }\end{array}$ \\
\hline \multirow{2}{*}{ with the $\mathrm{TiN} / \mathrm{CrN}$ coating } & sample No. 1 & 0.01 \\
\hline & sample No. 2 & 0.01 \\
\hline \multirow{2}{*}{ the serial of piston rings } & sample No. 3 & 0.04 \\
\hline & sample No. 4 & 0.04 \\
\hline
\end{tabular}

TABLE 2. Increasing the height of the working surfaces of the rings at a sliding speed of $1 \mathrm{~m} / \mathrm{s}$.

\begin{tabular}{ccc}
\hline \multicolumn{2}{c|}{ Variant of piston rings } & Height \\
of the rings & $\begin{array}{c}\text { working surfaces, mm } \\
\text { with the TiN/CrN coating sample No. 1 }\end{array}$ & 0.01 \\
& sample No. 2 & 0.02 \\
the serial of piston rings & sample No. 3 & 0.05 \\
& sample No. 4 & 0.07 \\
\hline
\end{tabular}

the $2^{\text {nd }}$ stage of testing at a speed of $1 \mathrm{~m} / \mathrm{s}$ is higher by 3.6 times, after the $3^{\text {rd }}$-by $17 \%$ relatively to the serial ones.

The microhardness of the rings samples with the ion-plasma coating after the $2^{\text {nd }}$ stage of testing decreases by 3.7 times when two speeds are combined, and after the $3^{\text {rd }}$-by 6 times at $1.3 \mathrm{~m} / \mathrm{s}$ and 11 times at $1 \mathrm{~m} / \mathrm{s}$, respectively, relative to the initial value of the traditional variant. The average microhardness of serial rings increases by 11 times from the initial indicator of the second stage of testing, and does not significantly change in the third (Figs. 7, $a$, $b)$.

The results of local X-ray microanalysis of friction working surfaces of the serial rings and $\mathrm{TiN} / \mathrm{CrN}$ hardened by multilayer nanocoating ones and tested at a speed of $1.3 \mathrm{~m} / \mathrm{s}$ are presented in Table 3 and 4 , and at a speed of $1 \mathrm{~m} / \mathrm{s}$, in Table 5 and 6 , respectively. The initial (before the tests) chemical composition and after the tests of the serial ring surface at a speed of $1.3 \mathrm{~m} / \mathrm{s}$ are shown in Table 3 (spectrum 1 and 2, respectively), and after testing at a speed of 1 $\mathrm{m} / \mathrm{s}$-in Table 5 (spectrum 2). Figure 8 shows the zones of determining the chemical composition of the initial surface (spectrum 1) and the friction zone (spectrum 2) of the serial ring at a speed of $1.3 \mathrm{~m} / \mathrm{s}$, and similarly, Figs. 9 (spectrum 1 and 2)-of the hardened ring tested at increased sliding speed. Figure 10 shows the zones for determining the chemical composition of the initial surface (spectrum 1) and the friction zone (spectrum 2) of the serial ring at 


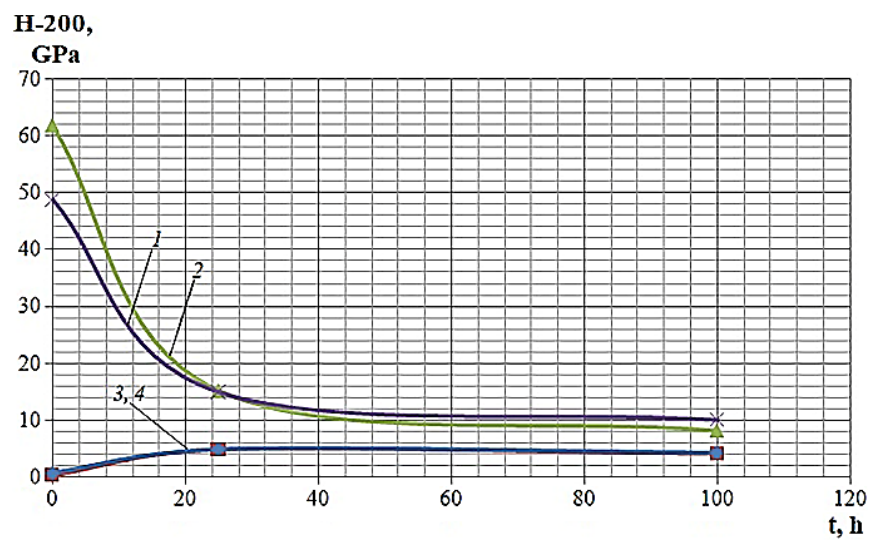

$a$

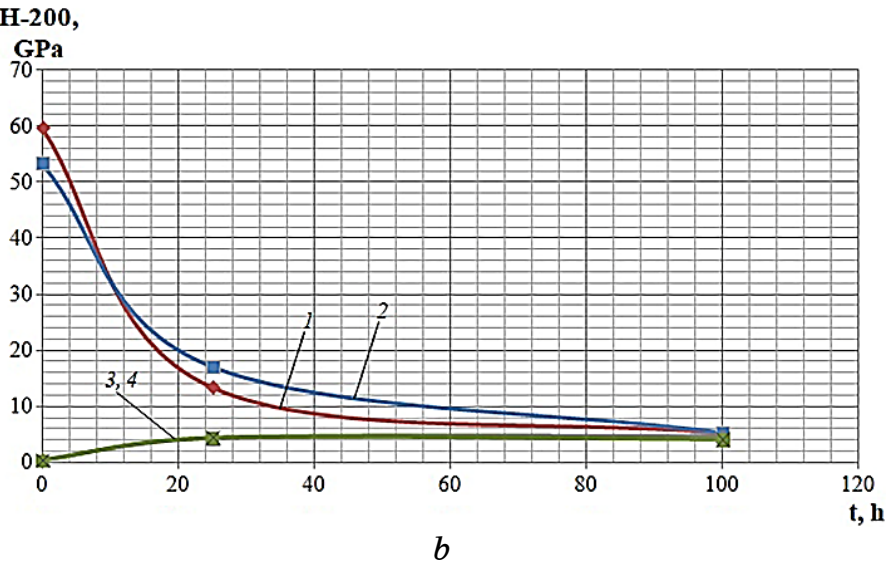

Figs. 7. Microhardness of the rings hardened by ion-plasma coating $(1,2)$ and the serial ones $(3,4): a$-after the testing at a sliding speed of 1.3 $\mathrm{m} / \mathrm{s} ; b$ - at a sliding speed of $1 \mathrm{~m} / \mathrm{s}$.

a speed of $1 \mathrm{~m} / \mathrm{s}$, and Figs. 11 shows the similar zones (spectrum 1 and 2) for the hardened ones at the same speed. The depth of the analysed zone was $2 \mu \mathrm{m}$.

It should be noted that tin in the samples of serial rings, due to their complete wear, was not found on either of the working surfaces in both test speeds. This is also confirmed by the increase in microhardness after the $2^{\text {nd }}$ and $3^{\text {rd }}$ stages of testing to the level of the base metal (grey iron).

At the same time, the effect of plastic deformation of the area was revealed, which is expressed in violation of the integrity of the tin coating of the surface adjacent to the friction one (Figs. 8 and 10). This is due to the Saint-Venant's effect [4] accompanied by the localization of the stress-strain state of nearby material, as a result 
TABLE 3. Chemical composition of the initial (spectrum 1) surface and friction zone (spectrum 2) of the serial piston ring tested at a speed of 1.3 $\mathrm{m} / \mathrm{s}$.

\begin{tabular}{c|c|c|c|c|c|c|c}
\hline Analysis zone & $\mathrm{C}$ & $\mathrm{O}$ & $\mathrm{Al}$ & $\mathrm{Si}$ & $\mathrm{Mn}$ & $\mathrm{Fe}$ & $\mathrm{Sn}$ \\
\hline spectrum 1 & 1.09 & - & 0.29 & 0.29 & - & 1.14 & 97.21 \\
spectrum 2 & 2.69 & - & 0.23 & 1.86 & 1.25 & 94.20 & - \\
\hline
\end{tabular}

TABLE 4. Chemical composition of the initial (spectrum 1) surface and friction zone (spectrum 2) of the ring coated by $\mathrm{TiN} / \mathrm{CrN}$ tested at a speed of $1.3 \mathrm{~m} / \mathrm{s}$.

\begin{tabular}{c|c|c|c|c|c|c|c|c|c|c}
\hline Analysis zone & $\mathrm{C}$ & $\mathrm{O}$ & $\mathrm{Al}$ & $\mathrm{Si}$ & $\mathrm{P}$ & $\mathrm{Ca}$ & $\mathrm{Ti}$ & $\mathrm{Cr}$ & $\mathrm{Mn}$ & $\mathrm{Fe}$ \\
\hline spectrum 1 & 0.8 & 0.13 & - & 0.16 & - & - & 14.5 & 83.77 & & 0.63 \\
spectrum 2 & 3.59 & - & 0.55 & 1.77 & 0.59 & 0.20 & 0.80 & 2.20 & 1.28 & 89.03 \\
\hline
\end{tabular}

TABLE 5. Chemical composition of the friction surface (spectrum 2) of the serial piston ring tested at a speed of $1 \mathrm{~m} / \mathrm{s}$.

\begin{tabular}{c|c|c|c|c|c|c|c|c|c|c}
\hline Analysis zone & $\mathrm{C}$ & $\mathrm{O}$ & $\mathrm{Al}$ & $\mathrm{Si}$ & $\mathrm{P}$ & $\mathrm{Ca}$ & $\mathrm{Cr}$ & $\mathrm{Mn}$ & $\mathrm{Fe}$ & $\mathrm{Sn}$ \\
\hline spectrum 1 & 1.09 & - & 0.29 & 0.29 & - & - & - & - & 1.14 & 97.21 \\
spectrum 2 & 2.23 & - & 0.23 & 1.65 & 0.52 & - & 0.42 & 1.66 & 93.28 & - \\
\hline
\end{tabular}

TABLE 6. Chemical composition of the friction surface of the ring with a TiN/CrN coating tested at a sliding speed of $1 \mathrm{~m} / \mathrm{s}$.

\begin{tabular}{c|c|c|c|c|c|c|c|c|c|c}
\hline Analysis zone & $\mathrm{C}$ & $\mathrm{O}$ & $\mathrm{Al}$ & $\mathrm{Si}$ & $\mathrm{P}$ & $\mathrm{Ca}$ & $\mathrm{Ti}$ & $\mathrm{Cr}$ & $\mathrm{Mn}$ & $\mathrm{Fe}$ \\
\hline spectrum 1 & 0.8 & 0.13 & - & 0.16 & - & - & 14.5 & 83.77 & & 0.63 \\
spectrum 2 & 4.41 & 0.91 & 0.60 & 1.25 & - & 0.77 & 10.76 & 39.08 & - & 42.22 \\
\hline
\end{tabular}

of which external loads are applied to the area of the working surface. The change in the macrorelief in the area of contact of the inclined surface to the working one corresponds to a value close to the size of $\cong 0.45-0.5 \mathrm{~mm}$.

The friction surface is characterized by the formation of longitudinal bands on the working surfaces of all analysed variants of the rings. They are formed due to friction in the direction of their movement during operation. The appearance of friction and graphite mesh on the working surface of the serial rings is also observed, which are presented in the form of individual, chaotically located and oriented black plate inclusions (Figs. 8 and 10, spectrum 2), 


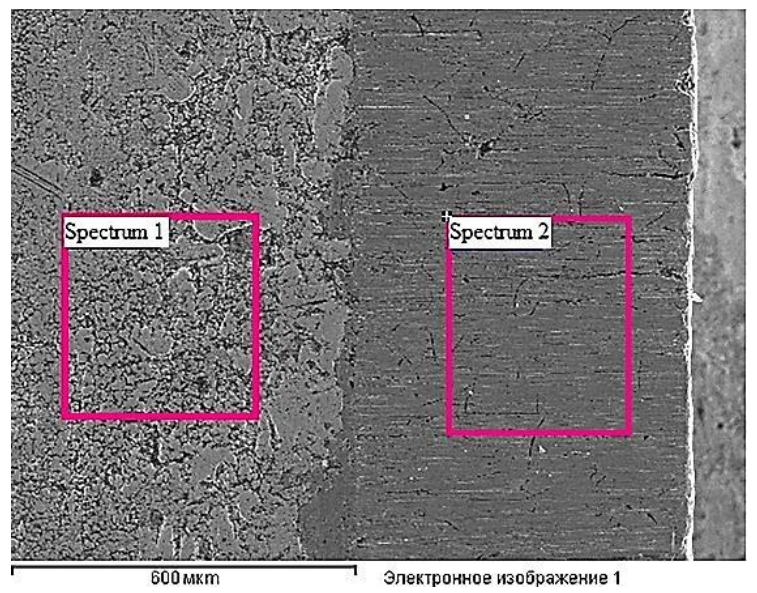

Figs. 8. A zone of determining the chemical composition of the initial surface (spectrum 1) and the friction zone (spectrum 2) of the serial ring tested at a speed of $1.3 \mathrm{~m} / \mathrm{s}$ (Table 3 ).

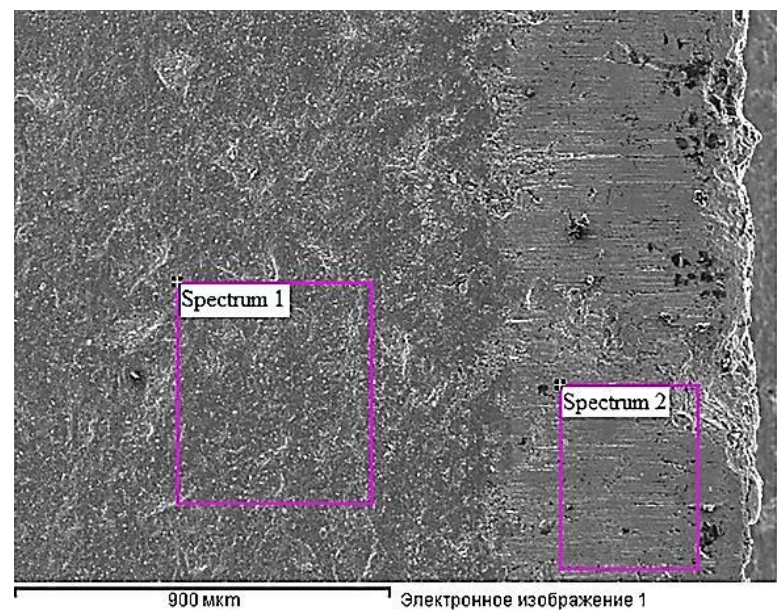

Figs. 9. An area of local chemical analysis of the initial surface (spectrum 1) and the friction surface (spectrum 2) of the ring with the $\mathrm{TiN} / \mathrm{CrN}$ coating after testing at a sliding speed of $1.3 \mathrm{~m} / \mathrm{s}$ (Table 4 ).

which corresponds to the original metal.

The analysis results of the initial surface of the samples tested at a speed of $1.3 \mathrm{~m} / \mathrm{s}$ of oil-scraper piston rings with the TiN/CrN multilayer ion-plasma coating showed that the initial ratio of the components of $\mathrm{Cr} / \mathrm{Ti}$ coating was 5.77. The proportion of components in the coating (in terms of the ratio of $\mathrm{Ti}$ and $\mathrm{Cr}$ ) after testing was $3 \%$ in total and the proportion of the base $(\mathrm{C}, \mathrm{O}, \mathrm{Si}, \mathrm{Mn}$, 


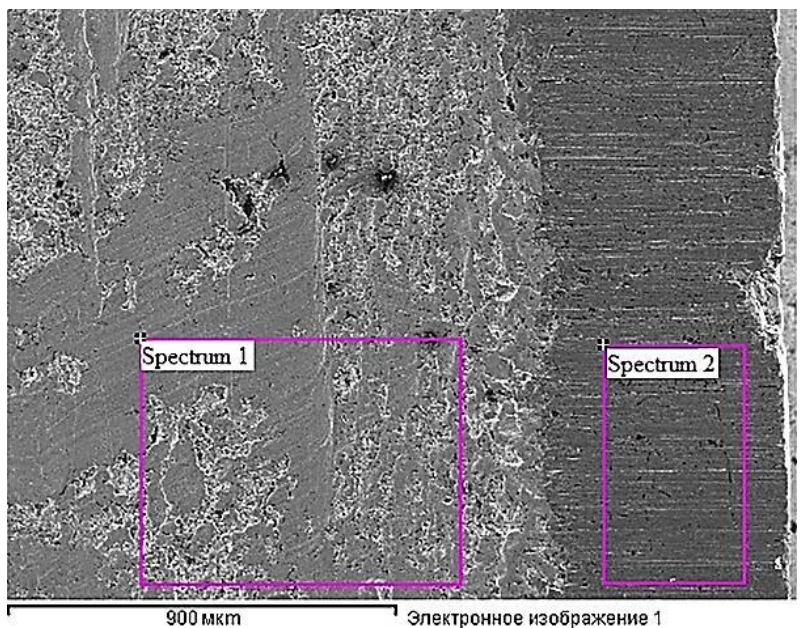

Figs. 10. A zone of determining the chemical composition of the initial surface (spectrum 1) and the friction zone (spectrum 2) of the serial ring tested at a sliding speed of $1 \mathrm{~m} / \mathrm{s}$ (Table 5 ).

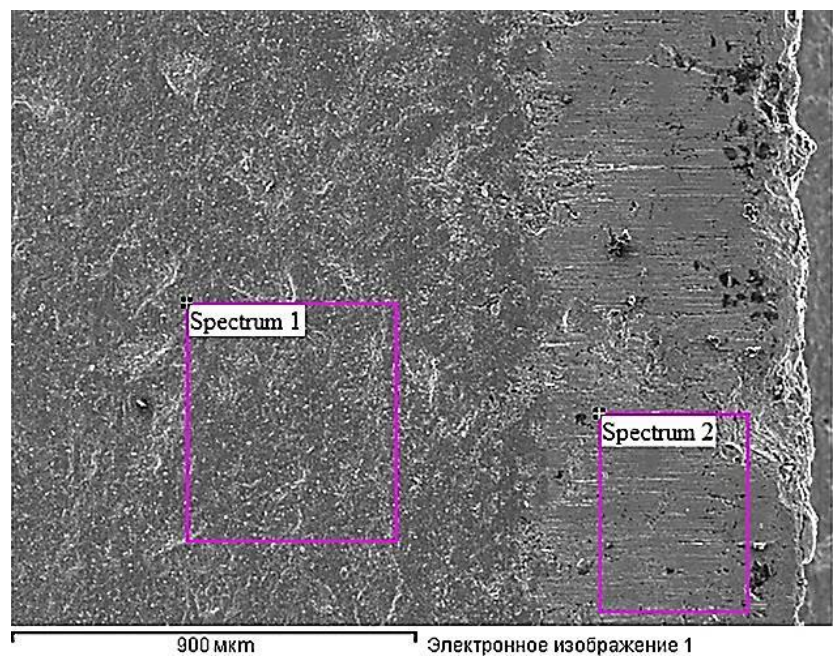

Figs. 11. Local chemical analysis zones of the initial (spectrum 1) and working surface (spectrum 2) of the ring with the TiN/CrN coating after testing at a sliding speed of $1 \mathrm{~m} / \mathrm{s}$ (Table 6).

Fe) increased up to $95.67 \%$ that indicates about significant wear of the deposited coating at this speed of friction. At the same time, the $\mathrm{Cr} / \mathrm{Ti}$ ratio decreased from 5.77 to 2.75 , where the proportion of $\mathrm{Cr}$ after the tests decreased by 38 times, and the proportion of $\mathrm{Ti}$ decreased by 18 times. 
According to the previously proposed calculation method [5], the residual thickness of the TiN/CrN coating after testing is $50 \mathrm{~nm}$. After the test, $\mathrm{Al}(0.55 \%), \mathrm{P}(0.59 \%)$ and $\mathrm{Ca}(0.2 \%)$ were found on the working surface. Perhaps the appearance of phosphorus is due to its partial transfer from the surface of the counterbody (phosphated sample of the cylinder liner) during testing, and the appearance of $\mathrm{Al}$ and $\mathrm{Ca}$ on the surface is possible due to friction under lubrication conditions, which, in turn, can be the result of local adhesion (characterized by weight gain of the ring samples at the $2^{\text {nd }}$ and $3^{\text {rd }}$ stages of testing).

Total proportion of the coating of the ring tested at $1 \mathrm{~m} / \mathrm{s}$ is $49.84 \%$, and that of the base is $48.77 \%$. The ratio of $\mathrm{Cr} / \mathrm{Ti}$ decreased to 3.63 compared with the original one. The proportion of Ti decreased by only 1.35 times, and $\mathrm{Cr}$ by 2.14 times in relation to the initial composition of the coating. The residual thickness of the coating was $850 \mathrm{~nm}$. At the same time, there is a partial transfer of phosphorus (Table $5, P=0.52 \%$ ) to the surface of the serial ring from its counterbody. The observed is due to the weight gain of this sample after the tests (Figs. 6).

At the same time, the fact of a pronounced structuring of the tin coating in the inclined surface of the serial ring adjacent to the friction zone with a length of $\cong 0.45-0.5 \mathrm{~mm}$ was revealed (Figs. 8 and 10, spectrum 1). It also indicates the degradation of the base metal and its low resistance to cyclic exploitation. In this case, in rings with the ion-plasma coating, a similar structuring of an inclined surface is not observed (Figs. 9 and 11, spectrum 1), which is explained by the high degree of the coating resistance to the development and propagation of deformations caused by cyclic friction.

The characteristic longitudinal stripes on the working surface of both variants of the rings are formed due to friction in the direction of movement of the ring during operation. The formation of a graphite grid in the working surface of the serial rings is also observed, which are also presented in the form of individual, randomly arranged and oriented elongated and black inclusions (Figs. 8 and 10, spectrum 2) that corresponds to the structure of the original metal.

To predict diffusion processes and wear by changing the proportion of coating during friction, a method [6] was proposed, which consists in estimating changes in the local chemical composition in the friction zone taking into account the initial surface of the piston rings in depth taking into account the coating area, the transitional layer and the layer formed after operation, that is a general change in the content of components in the coating-base system.

As shown in Table 7, the initial ratio of the base element of cast iron $(\mathrm{Fe})$ to the elements of the ion-plasma coating of the piston 
TABLE 7. The ratio of the components of the substrate to the coating at different sliding speeds.

\begin{tabular}{|c|c|c|c|c|}
\hline $\begin{array}{c}\text { Sliding } \\
\text { speed, } \mathrm{m} / \mathrm{s}\end{array}$ & $\begin{array}{c}\text { Concentration } \\
\text { of } \mathrm{Fe}, \%\end{array}$ & $\begin{array}{c}\text { Coating of the } \\
\text { ring }(\mathrm{Ti}+\mathrm{Cr}) \\
\%\end{array}$ & $\begin{array}{c}\text { Ratio } \\
(\mathrm{Fe}) /(\mathrm{Ti}, \mathrm{Cr})\end{array}$ & $\begin{array}{c}\text { Characteristic of } \\
\text { transition zone }\end{array}$ \\
\hline $\begin{array}{l}\text { Initial state } \\
\text { of the system }\end{array}$ & 0,63 & 98,27 & 0,006 & $\begin{array}{l}\text { No diffusion, high wear } \\
\text { resistance }\end{array}$ \\
\hline 0,7 & 23,4 & 73,6 & 0,32 & $\begin{array}{l}\text { Low diffusion of Fe and } \\
\text { high wear resistance }\end{array}$ \\
\hline 1,0 & 42,22 & 49,84 & 0,85 & $\begin{array}{l}\text { Moderate diffusion of } \\
\text { Fe and high wear re- } \\
\text { sistance }\end{array}$ \\
\hline 1,3 & 89,03 & 3,0 & 29,7 & $\begin{array}{c}\text { Diffusion of } \mathrm{Fe} \text { and } \\
\text { coating wear increase } \\
\text { sharply }\end{array}$ \\
\hline 1,6 & 94,2 & absent & $\begin{array}{l}\text { initial state } \\
\text { of the metal }\end{array}$ & $\begin{array}{l}\text { Wear of the coating, } \\
\text { low wear resistance }\end{array}$ \\
\hline
\end{tabular}

ring $(\mathrm{Ti}, \mathrm{Cr})$ is 0.006 . Operation at a speed of $0.7 \mathrm{~m} / \mathrm{s}$ intensifies the processes of diffusion and destruction of the coating on graphite inclusions and the ratio is 0.32 (increases 53 times). After operation at a speed of $1 \mathrm{~m} / \mathrm{s}$, the ratio increases by 142 times to 0.85 relative to the initial state with the coating, which indicates about significant increase of the Fe diffusion into the coating due to friction already with increasing speed. At a speed of $1.3 \mathrm{~m} / \mathrm{s}$, the total $\mathrm{Fe}$ content is increased by 4950 times, to 29.7 from the original. At a sliding speed of $1.6 \mathrm{~m} / \mathrm{s}$, as a result of friction, the ion-plasma coating completely wears out on the ring surface. At the same time, for a speed of $0.7 \mathrm{~m} / \mathrm{s}$, an initial (relatively low) Fe content in the coating can be observed, which characterizes a high level of wear resistance and a slight diffusion of iron from the substrate.

The results of the change in the concentration of iron and the components of the coating at different sliding speeds are shown in Figs. 12. As can be seen from the graph, a change in one of the most important parameters of operation (sliding speed) affects the intensification of the coating wear process and local diffusion of iron toward the surface. This is especially noticeable at sliding speeds of 1.3 and $1.6 \mathrm{~m} / \mathrm{s}$ (Figs. 12).

Based on the results of an X-ray microanalysis, the scanning probe of which forms a spherical zone when evaluating the chemical composition of the ring friction surface with a penetration radius of $2 \mu \mathrm{m}$, a simultaneous assessment was made of the wear amount of the coating and diffusion of the piston rings main element of $\mathrm{Fe}$ as 


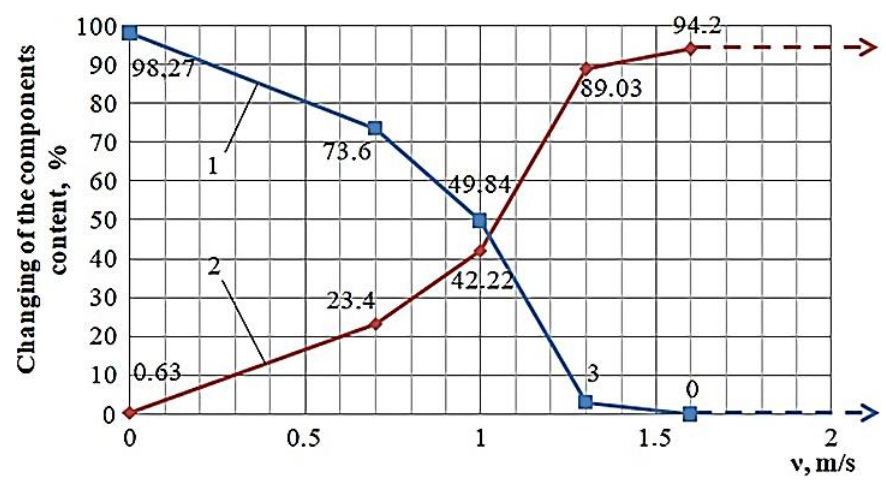

Figs. 12. Dependence of changes in the concentration of the components of the coating and the base at different sliding speeds: 1 - the basic components of the ion-plasma coating $(\mathrm{Ti}+\mathrm{Cr})$; 2 -the basic component of the serial ring $(\mathrm{Fe})$.

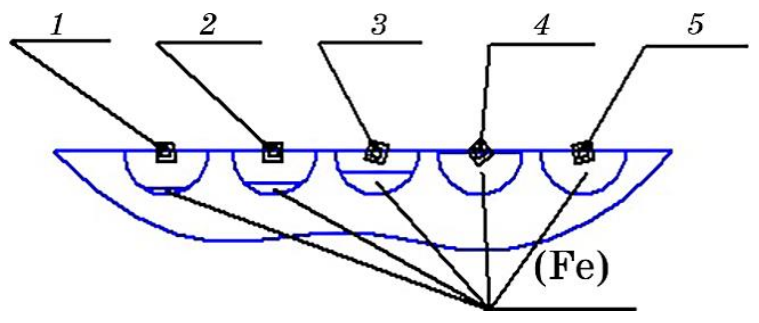

Figs. 13. Scheme of changes in the concentration of the base $\left(S_{(\mathrm{Fe})}\right)$ and coating $\left(S_{(\mathrm{Ti}, \mathrm{Cr})}\right): 1$-initial coating analysis zone $\left(S_{(\mathrm{Ti}, \mathrm{Cr})}=5.9 \mu \mathrm{m}^{2}, S_{(\mathrm{Fe})}=0.4\right.$ \left.${\mu \mathrm{m}^{2}}^{2}\right) ; 2$-analysis zone at a speed of $0.7 \mathrm{~m} / \mathrm{s}\left(S_{(\mathrm{Ti}, \mathrm{Cr})}=5.3 \mu \mathrm{m}^{2}, S_{(\mathrm{Fe})}=1.0\right.$ $\left.\mu \mathrm{m}^{2}\right)$; 3 -analysis zone at a speed of $1 \mathrm{~m} / \mathrm{s}\left(S_{(\mathrm{Ti}, \mathrm{Cr})}=3.8 \mu \mathrm{m}^{2}, S_{(\mathrm{Fe})}=2.5\right.$ \left.${\mu \mathrm{m}^{2}}^{2}\right)$; 4 -analysis zone at a speed of $1.3 \mathrm{~m} / \mathrm{s}\left(S_{(\mathrm{Ti}, \mathrm{Cr})}=0.2 \mu \mathrm{m}^{2}, S_{(\mathrm{Fe})}=6.1\right.$ $\left.\mu \mathrm{m}^{2}\right)$; 5-analysis zone at a speed of $1.6 \mathrm{~m} / \mathrm{s}\left(S_{(\mathrm{Ti}, \mathrm{Cr})}=0.0 \mu \mathrm{m}^{2}, S_{(\mathrm{Fe})}=6.3\right.$ $\left.\mu \mathrm{m}^{2}\right)$.

a result of operation. For this purpose, at each sliding speed, the cross-sectional area of the residual coating was calculated from the content of $\mathrm{Ti}, \mathrm{Cr}$, and Fe (Figs. 13), using the previously developed method for such coatings [5]. After that, the difference in the changes of the chemical composition before and after the test of the coating and the base separately (\%) were related to their area. The difference in the chemical composition and area in the hardened ring corresponds to an estimate of the local wear value, and the same difference corresponds to an increase in the base fraction-the level of diffusion of Fe. Table 8 presents the calculation results, and Figs. 13 presents their influence.

Studies have shown that the wear resistance of such a coating 
TABLE 8. The ratio of the percentage change in the elements of the coating and the basics of the rings.

\begin{tabular}{|c|c|c|c|c|}
\hline $\operatorname{s}_{\Xi}^{\infty}$ & Residual coating & Base area & $\begin{array}{c}\text { Ratio } \\
\left|(\mathrm{Ti}, \mathrm{Cr})_{\text {исх }}-(\mathrm{Ti}, \mathrm{Cr})_{\mathrm{rp}}\right|\end{array}$ & $\begin{array}{c}\text { Ratio } \\
\underline{\mid(F e)_{\text {ИСх }}-(\mathrm{Fe})_{\mathrm{тр}}}\end{array}$ \\
\hline 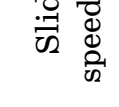 & $\operatorname{area} S_{(\mathrm{Ti}+\mathrm{Cr})}, \mu \mathrm{m}^{2}$ & $S_{(\mathrm{Fe})}, \mu \mathrm{m}^{2}$ & $\begin{array}{c}\left|S_{(\mathrm{Ti}, \mathrm{Cr})_{\text {исх }}}-S_{(\mathrm{Ti}, \mathrm{Cr})_{\text {тр }}}\right| \\
\% / \mu \mathrm{m}^{2}\end{array}$ & $\begin{array}{c}\left|S_{(\mathrm{Fe})_{\text {исх }}}-S_{(\mathrm{Fe})_{\text {тр }}}\right| \\
\% / \mu \mathrm{m}^{2}\end{array}$ \\
\hline 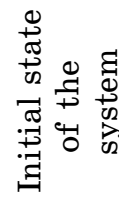 & 5.9 & 0.4 & 16.7 & 1.6 \\
\hline 0.7 & 5.3 & 1.0 & 41.1 & 38 \\
\hline 1.0 & 3.8 & 2.5 & 23 & 19.8 \\
\hline 1.3 & 0.2 & 6.1 & 16.7 & 15.5 \\
\hline 1.6 & 0.0 & 6.3 & 16.7 & 16 \\
\hline
\end{tabular}

substantially depends on nanolayers with titanium nitrides, which are differed by higher hardness. Increasing their thickness to further increase wear resistance in other conditions may not be effective due to the propensity for damage under operating conditions. Probably, if necessary, this problem can be solved by increasing the number of nanolayers TiN and reducing the thickness of $\mathrm{CrN}$.

\section{CONCLUSIONS}

The technology of hardening of piston rings by multilayer ionplasma coating $\mathrm{TiN} / \mathrm{CrN}$ is proposed. The coating was deposited with an arc current $I_{d}=100 \mathrm{~A}$ and the substrate bias voltage $U_{\mathrm{cm}}=-200 \mathrm{~V}$. Alternately, 6 layers of $\mathrm{CrN}$ and 5 layers of TiN were applied, after spraying with a pure $\mathrm{Cr}$ sublayer $\cong 50 \mathrm{~nm}$ of thickness. The thickness of the TiN layer is $49 \mathrm{~nm}$, and the CrN layer is $240 \mathrm{~nm}$. The $\mathrm{CrN} / \mathrm{TiN}$ ratio was 5.8. The total thickness of the multilayer coating is $1.7 \mu \mathrm{m}$.

Estimated wear characteristics of the oil-scraper piston rings at different sliding speeds $(0.7-1.6 \mathrm{~m} / \mathrm{s})$. As established, the wear occurs both in weight and in increase of the height of the working surface. The test results of the rings during hardening with a multilayer ion-plasma coating showed that the weight wear rate decreases by 12 times at a sliding speed of $1.3 \mathrm{~m} / \mathrm{s}$ and by 15.7 times at a speed of $1 \mathrm{~m} / \mathrm{s}$, which correspond to different values of friction path. The height of the working surface in such rings is kept more 
stable to the original size with respect to the serial.

The evaluation of the local chemical composition of the friction surface of the piston rings with $\mathrm{TiN} / \mathrm{CrN}$ coating was carried out in tests with a sliding speed of $1.3 \mathrm{~m} / \mathrm{s}$, equal to $468 \mathrm{~km}$ of the traversed friction path. At the same time, the chromium after tests decreased by 38 times, and the titanium-by 18 . Tests at a sliding speed of $1 \mathrm{~m} / \mathrm{s}$ are characterized by a decrease of the titanium by only 1.35 times, and the chromium by 2.14 relative to the original composition.

The fact of structurization of an inclined surface adjacent to the working surface of the serial piston ring is revealed by an amount close to the height of the working surface $(\cong 0.45-0.5 \mathrm{~mm})$. This is especially true for piston rings without a special multilayer coating, which can lead to degradation of the structure in this zone and the onset of damage.

Based on the obtained results about the effect of operating parameters and the features of structure formation in the process of friction, it is recommended to use multilayer coatings, which differ by levels of hardness and their ratio that determines the performance and reliability of the product.

\section{REFERENCES}

1. T. S. Skoblo, A. I. Sidashenko, E. A. Satanovskii, A. K. Oleinik, and T. V. Mal'tsev, Mat. Sci., 53, Iss. 4: 501 (2018); https://doi.org/10.1007/s11003-018-0102-6.

2. T. S. Skoblo, A. I. Sidashenko, A. V. Taran, R. M. Muratov, and T. V. Maltsev, Povyshenie Stoikosti Porshnevykh Kolets Mnogosloinym Ionno-Plazmennym Pokrytiem [Durability Increase of Piston Rings by Multilayer Ion-Plasma Coating] (Moscow: Tekhnologiya Mashinostroyeniya: 2019), vol. 3, p. 24 (in Russian).

3. T. S. Skoblo, A. I. Sidashenko, I. E. Garkusha, A. V. Taran, R. M. Muratov, and T. V. Maltsev, Problems of Atomic Science and Technology, 6, No. 118: 304 (2018).

4. V. V. Kalashnikov and M. I. Karyakin, Prikladnaya Mekhanika i Tekhnich. Fizika, 47, No. 6: 129 (2006) (in Russian); http://www.sibran.ru/upload/iblock/e3c/e3c2e51ba6e64e0b53ef244424f84df6.pdf.

5. T. S. Skoblo, O. I. Sidashenko, I. E. Garkusha,V. S. Taran, R. M. Muratov, E. A. Satanovskii, O. K. Oleinik, T. V. Maltsev, I. M. Rybalko, and P. S. Syromyatnikov, Sposib Prohnozuvannya Dovhovichnosti Efektyvnoyi Tovshchyny Bahatosharovoho Zmitsnyuyuchoho Pokryttya Porshnevykh Kilets' [Method of Predicting the Durability of Effective Thickness of Multilayer Hardened Coating of Piston Rings] (Patent No. 117673 of Ukraine, F16J 9/00 (Korysna Model', No. 13) (2017)) (in Ukrainian).

6. T. S. Skoblo, O. I. Sidashenko, I. E. Garkusha,V. S. Taran, R. M. Muratov, E. A. Satanovskii, O. K. Oleinik, T. V. Maltsev, and V. N. Romanchenko, Sposib Prohnozuvannya Dyfuziyi Komponenta Osnovy Porshnevykh Kilets' $v$ 
Ionno-Plazmove Pokryttya pry Riznykh Parametrakh Tertya [Method of Predicting the Diffusion of the Component of the Base of the Piston Rings in the Ion-Plasma Coating at Various Friction Parameters] (Patent No. 130854 of Ukraine, F16J 9/00 (Korysna Model', No. 24) (2018)) (in Ukrainian). 